\title{
Teaching Anthropology
}

Vol. 10, No. 4, pp. 92-109

\section{The Fires Within Us and the Rivers We Form}

\author{
The River and Fire Collective ${ }^{1}$ : Antony Pattathu ${ }^{2}$, Olivia Barnett-Naghshineh ${ }^{3}$, Oda-Kange \\ Midtvåge Diallo ${ }^{4}$, Nico Miskow Friborg ${ }^{5}$, Zouhair Hammana ${ }^{6}$, Lisette van den Berg, \\ Angelo Camufingo ${ }^{8}$, Victoria Klinkert ${ }^{9}$, Andrew Judge $\left(\right.$ Mkomose $^{10}$, Shukti Chaudhuri- \\ Brill $^{11}$, Sherry Fukuzawa ${ }^{12}$, Naasiha Abrahams ${ }^{13}$, Jonathan Ferrier ${ }^{14}$ \\ ${ }^{2}$ University of Tübingen, Germany; ${ }^{3}$ University of Exeter, United Kingdom; ${ }^{4}$ Norwegian University of Science and Technology, \\ Norway; ${ }^{5}$ University of Stavanger, Norway; ${ }^{6}$ Erasmus University Rotterdam, The Netherlands; ${ }^{7}$ Leiden University, The Netherlands; \\ ${ }^{8}$ University of Potsdam, Germany; ${ }^{9}$ SOAS University of London, United Kingdom; ${ }^{10}$ Algoma University, Canada; ${ }^{11}$ New York \\ University Paris, France; ${ }^{12}$ University of Toronto Mississanga, Canada; ${ }^{13} \mathrm{KU}$ Lewven, Belgium; ${ }^{14}$ Dalhousie University, Canada
}

\begin{abstract}
This paper is a creative, poetic and experimental intervention in the form of collective reflections and writings on Anthropology, as the discipline we have experienced and/or been a part of within the University. It is also a reflection on the process of how the authors came together to form the River and Fire Collective. As a collective we have studied, worked and taught in more than 15 universities, and the aspects we point to here are fragments of our experiences and observations of the emotionality of the discipline. These are experiences from different forms of Anthropology from Northern Europe and settler-colonial contexts including Great Turtle Island Canada and Aotearoa New Zealand. In a metaphorical manner we invite the reader to our collective fireside dialogues and reflections, to be inspired, to disagree or agree and to continue a process of transformation. The paper sets out to provocatively question whether Anthropology is salvageable or whether one should 'let it burn' (Jobson, 2020). Exploring this question is done by way of discussing decolonial potentialities within the discipline(s), the classroom and exploring fire and water as a radical potential to think through the tensions between abolition and transformation. The reflections engage with concepts of decolonization, whiteness/white innocence, knowledge creation and -sharing, the anthropological self, ethics and accountability and language. The paper emphasizes Anthropology's embeddedness in colonial narratives, structures and legacies and draws attention to how these colonial, able-bodied realities are being continuously reaffirmed through multiple educational practices and methodologies. It suggests that collectivity in writing, thinking and being is part of a healing process for those of us feeling our way through colonial continuities and prospective potentialities of Anthropology.
\end{abstract}

Keywords: decolonization, anthropology, education, fire, white innocence, collaborative writing, reflexivity

This paper is a set of collective reflections and interventions on Anthropology, both as the discipline we have all experienced, worked and studied in. It sets out to question whether Anthropology is salvageable or whether we should 'let it burn'. We acknowledge that the particular colonial continuities in each settler-colonial Anthropology context are different and cannot be generalized. However, as Black, Indigenous and POC, queer, nonbinary and trans anthropologists we recognize patterns throughout our experiences of Anthropology. The discipline is made up of all those points of contact, where we get touched and inspired by the discipline; conferences, classrooms, meetings, associations, publications, processes of peer review - and curriculum. But

\footnotetext{
${ }^{1}$ Primarily this piece was about writing together, and therefore we would like our cited reference to not be our names but instead "The River and Fire Collective". However, recognizing that to each receive a publication, as per required for academic recognition, we also need to use our individual names. Hence as a group we had to discuss how we would decide the order of names. We know that the order of names following will never do justice to the process that we had, but we are tied to this system of individual authorship that we are also trying to write against in this piece. This reduces the qualitative experience of what this process has offered to all of us, especially during lockdown when our regular group meeting meant we had a sense of community despite physical isolation. Everyone's presence and inputs has been critical to this final piece. However, the order has been decided according to input of material and affective labour in coordinating the collective process, time spent writing and editing and contribution of ideas and analysis.
} 
there are also spaces that push against this, some of which we are part of and many that we do not yet know of. We came to be a collective through meeting each other at the Anthropology of Race and Ethnicity Network meeting (Leiden 2019), the European Association of Social Anthropology conference (2019 and 2020), the Association of Social Anthropology (UK) conference 2019, the Decolonial Summer School (2018) and through teaching together within our universities. The COVID-19 pandemic meant that we were all able to meet frequently online and get to know each other as a group; we are yet to all be together in person. We want to acknowledge that we are not trying to make claims about Anthropology as a whole but what we know of its practices based on our own experiences and observations. We realize that what the discipline is and how it is taught differs between social, political and cultural contexts. ${ }^{2}$ We refer to Anthropology (with a capital A) as the hegemonic form that we have all experienced and been shaped by in the anthropology classroom located within Northern European and settler-colonial classrooms hence we aim to re-educate ourselves in critical knowledges and frameworks that were not part of the main curricula.

\section{"We begin by continuing to let anthropology burn"}

After attending the AAA conference in 2018 in San Jose, Ryan Jobson reflected on the lack of ability for Anthropology 3 to truly face up to its ongoing relationship to racial and colonial inequalities that continue in the form of anti-Black state violence and unequal distribution in the impacts of climate disaster. As fires raged on in California, anthropologists pushed on through to conduct their conference as though nothing was happening. He suggests that much like the fires that are increasingly ravaging the planet, Anthropology too is burning, and there is little being done to rectify its liberal inability to contribute to radical transformation both within and outside of the discipline. Ryan Jobson ends his year in review essay in 2019 with, "We may begin by letting anthropology burn” (Jobson, 2020, p. 267). What then does 'letting anthropology burn' mean, and to be more abstract: what does it mean to let something burn? Does 'to let something burn' imply that something has been burning all along, which is to say: has anthropology been burning and we continue to let it burn? Or are we to add to the fire and accelerate the process? What we can be sure of is that burning, and thus fire, in some shape or form plays a part in a praxis of abolition and regeneration. There are different epistemologies of fire, which can give us perspectives on what it means to let something burn that are not destructive.

Whether we would understand fire by way of Prometheus, as the Greek story goes, who brought fire to Earth, or, by way of the Zoroastrian eternal flame, with an ultimate respect for fire's energy, or as our Anishinaabe ${ }^{4}$ co- $^{-}$ authors suggest, fire, or Ishkode in the language, is a sacred central pillar from which all aspects of being in the world resonate outward. For the Anishinaabe fire is connected to the heart, or Ode in the language. Ode being the muscle that carries sacred water or blood throughout the body, with each beat or flash of electricity. The word for heart in Anishinaabe language is also found in the word for village, or Odena as the place where the people's hearts gather. Thus, for the Anishinaabe, it becomes the responsibility of each individual to care for the hearts of others. All others. Including all other beings. It is up to us all to ensure the sacred water, or blood, of all others is nurtured in such a way, so as to ensure their fire or Ishkode burns bright (Stark, 2012). Learning from the Anishinaabe concept of fire, means centering the need to care for all beings in our practices of teaching and researching.

When treated with reverence, fire can support life and unity. Not just an ending, it can make way for new beginnings, a clearing of what exists in order to create space for something else that can be nurtured and grow. After the fire, water and rivers are needed to nurture the earth and the plants. As humans can't live in places where there is only fire or water, the process of abolition needs these two energies. Breaking, accepting and cherishing these elements. This is the inspiration for how our name emerged, this is how we became the River and Fire Collective.

\footnotetext{
${ }^{2}$ It is important to highlight the work of networks such as the World Anthropologies Network\# which has been pushing and putting into relief a pluriversal vision and praxis of anthropology located outside the metropole and other hegemonic centers.

${ }^{3}$ It must be noted that our analyses are not aimed at individuals. Pointing out generalzing effects and outcomes of wider structural issues does not take away from individual exceptions. However, as important as these exceptions (or anomalies) are, on a structural level they do not eliminate shared benefits and privileges (yet). A "Not all anthropologists"-narrative doesn't dissolve colonial continuities and risks detracting from our systemic critique.

4 The Anishinaabe peoples are an Algic speaking Indigenous group native to Turtle Island Canada whose land base extends from the East Coast to the Rocky Mountains
} 


\section{The River and Fire Collective ${ }^{5}$}

In one of our meetings, Mkomose - Andrew Judge - shared with us a story of his friend Juan Sánchez, who likened life to be like a river (from a poem originally by Juan Shiles, approx. 1758). Sometimes we are the water flowing (making change), sometimes we are the foam dancing (holding space for transformation), and at times we are the stone, still and slow to move. This can be interpreted in multiple ways. As part of this analogy, in the context of Anishinaabe worldview, the river is a literal reflection of the flow of our blood and the fire a literal reflection of the beating of the heart. In this way fires burn within us and the river flows through us. After hearing this metaphor, we felt that collectively (and individually) we are like rivers joining and running together to create this piece. This also helps some of us make sense of how we feel within the discipline, sometimes wanting radical change, sometimes seeing the value of maintaining elements and sometimes wanting to do something new and rarely remaining fixed in one position. We bring our changing positions together, similar to how adrienne maree brown $(2017$, p. 6) puts it, we are "more water joining the river."

The river stands for the multitude that we represent, for our histories, identities and intellectual genealogies which have all come together here. We don't always agree, we feel differently about what it means to decolonize anthropology. For example, some of our collective believe (extractive) fieldwork should be abolished altogether and some see the potential for dialogue and mutual understanding depending on who we work with, how it is done, and who it is for. We see the river as representing the multiplicity of not only our positions, but the way anthropology has decolonial energies and potentials. Rivers sometimes slowly erode, the stone stays still and maintains the status quo, the foam dances and disrupts, producing new movements and spaces for something that is decolonial. Rivers ultimately can flood and destroy, like fires, making way for something new but also causing grief. They also provide much needed hydration. Our work has hydrated and nourished us in the midst of the challenges we describe throughout the journal.

\section{"We begin by letting anthropology burn" and by "building life-affirming institutions"}

Fire is destructive and constructive, it is multiple, both giving life and destroying. This abolitionist understanding of fire becomes important in thinking about 'letting anthropology burn' (Jobson, 2020). Ruth Wilson Gilmore reminds us that 'abolition is about presence, not so much about absence, it is about building life-affirming institutions' (Gilmore, 2007). Can we let something burn down whilst simultaneously building 'life-affirming institutions' and allowing for regeneration?

We argue that if we do not start to seriously consider abolitionism within the discipline (Shange, 2019) in order to salvage what we consider its transformative decolonial potentials, then the destructive fires within the discipline will destroy these bright transformative kernels itself.

We can conceptualize fire as life-affirming, and at the same time as a potentially transformative element towards institutions and oppressive structures when the fires within us are united and the rivers we are, flow. The white supremacist, colonial, capitalist, ableist, cis-heteropatriarchy ${ }^{6}$ that we've faced and continue to face attempts to extinguish the 'life-affirming', transformative fires we have struggled to uphold. These systems of tyranny continuously interrupt the flow of our rivers. Keeping these fires alive, nourishing them and creating space for something else to grow is to work towards dismantling and destructing capital accumulation, whiteness, ${ }^{7}$ white

\footnotetext{
${ }^{5}$ Our name echoes the work of the Combahee River Collective (1983) and whilst the fire and river emerged in our conversations independently, we are nonetheless indebted to and inspired by their work that created space for a multitude of voices.

${ }^{6}$ Here we are inspired by Audre Lorde (1984), bell hooks (1989/2014) and Patricia Hill Collins' (2000) work on how white supremacy, colonialism, capitalism, patriarchy and ableism are interlocked systems of power. And further, work which interlinks Black feminist thought with transfeminism (Green \& Bey, 2017; Raha, 2017) to describe how the white supremacist, colonial, capitalist, ableist, cis-hetero patriarchy devalues, dehumanizes and configures especially women, queer and trans people who are Black, Indigenous, People of Color as disposable and killable.

7 The concept of "white" is a social construction to denote privilege and power and not an identity that needs reaffirming in a context of oppression and dehumanization. For this reason, Black and Indigenous are spelled with a capital and white is not.
} 
supremacy, ableism, cis heteronormativity ${ }^{8}$, and patriarchy, or in other words: to be life-affirming is to be destructive of coloniality ${ }^{9}$. But, as the Zoroastrian understanding of fire teaches us, the fire will always (continue to) burn. So, if we take Ruth Wilson Gilmore's words seriously, then perhaps we can think about a way of treading through the burning embers of Anthropology, burning the soles of our feet and inhaling the smoke. Whilst we carefully step, we build life-affirming institutions offering an alternative to dominant versions of Anthropology.

Savannah Shange (2019) reminds us that abolition is not about winning or gaining control. For her, mapping an abolitionist anthropology considers who loses by institutionally claiming an ever more inclusive we - often claimed for the greater good of the discipline. She stresses the need of facing anti-Black violence, and the razing of the settler-slaver society for an abolitionist anthropology. Abolition needs to go hand in hand with reconstruction, as we understand the force of the fire as destructive and life affirming to create new presences of anthropology (Shange 2019, p. 3-4, 7). This piece (and our process) is an attempt at presencing; a way of doing and being and trying to write a collaborative, abolitionist practice and politics of anthropological teaching and learning into existence. Perhaps it is a way of rehearsing instead of reciting together (as Ruth Wilson Gilmore has put it ${ }^{10}$ ); imagining otherwise (Olufemi 2021). As Christina Sharpe writes, we hope to "remake the world. Some of us have never had any other choice" (Sharpe, 2016, para. 12).

Our rehearsal is a matter of working through an understanding of coloniality that comes from our engagements with Indigenous knowledge and practice, anti- and decolonial theories, Black feminism, Black studies, Queer and Trans studies and critical disability justice. We are working with an expansive concept of coloniality in which we, inspired by María Lugones (2010, p. 742), understand "categorical, dichotomous, hierarchical logic as central to modern, colonial, capitalist thinking about race, gender, and sexuality." This entails: the extinction of Indigenous life, lifeforms, communities; stealing of land and resources (Maldonado-Torres, 2007); the imposition and influence of ideas and structures such as gender as binary, essentialist and static, the naturalization of EuroChristian heteronormativity, monogamy, and the reproductive nuclear family as well as ableism; "disability justice asserts that ableism helps make racism, Christian supremacy, sexism, and anti-queer- and trans structures possible, and that all those systems of oppression are locked up tight" (Piepzna-Samarasinha, 2019, p. 22).

We channel the fires' energy in our classrooms (and kitchens, gardens or forests), with our students, elders and teachers. It is the fire that keeps us in connection with our hearts, a life-affirming fire, kept alive in a hearth of learning. Around the fire we sit as a collective. While our engagements in abolitionist struggles or struggles to dismantle white supremacist, colonial, capitalist, ableist, cis-hetero patriarchal systems of power within and outside of Anthropology have led us to the fire in different ways, we come to this collective intervention from and with different experiences and struggles. Many of us experience racism and discrimination in our daily lives as well as in the academy, being positioned as "European Others" (El-Tayeb, 2011), some of us experience the particularities of anti-Muslim racism, anti-Blackness and/or colourism, some of us are Indigenous, some of us are white. We are also differently positioned and affected by class, the gender binary and sexism, particularly misogynoir ${ }^{11}$, cis-heteronormativity, and able-bodied, sanist ${ }^{12}$ (excluding of neurodiversity ${ }^{13}$ ) and anti-trans

\footnotetext{
${ }^{8}$ Cis-normativity is a structure that renders cis people (see footnote 26) the norm, assumes everyone to be cis and in turn configure trans people as deviant, pathological and in need of correction. Cis-normativity is closely linked to heteronormativity and to the gender binary. Anti-trans structures, especially when intersecting with anti-Blackness and misogyny, severely affect trans people's life chances and make trans people disposable and killable (Spade, 2011; 2015; Raha, 2017). It also marginalizes non-binary and gender non-conforming people.

${ }^{9}$ Here, we are thinking about what in many European classrooms is considered part of the anthropological canon and what dominates many first-year curriculums, how many anthropologists conceptualize fieldwork in the classical Malinowski sense; who gets professorships, whose names are remembered, and the ways many disciplinary spaces are organized. ${ }^{10}$ https://pcp.gc.cuny.edu/2021/05/ruth-wilson-gilmore-and-paul-gilroy-discuss-new-stuart-hall-volume/

${ }^{11}$ Misogynoir describes the intersection of Anti-Black racism and misogyny. Examples for misogynoir are the oversexualization of Black women or the "medical" assumption of them having a higher pain threshold. The term was coined by the queer Black feminist Moya Bailey in 2010.

12 Sanism means the discrimination of people who have mental health conditions, or who are labelled or perceived as having a "mental illness".

${ }^{13}$ Neurodiversity refers to the natural and important variations in how human minds think. These differences can include autism, attention deficit hyperactivity "disorder", dyspraxia, dyslexia, dyscalculia, Tourette Syndrome, and others. The social dynamics that exert power over other forms of diversity also impact neurodivergent people. (Neurocosmopolitanism, The National Symposium on Neurodiversity)
} 
structures, in and outside of the academy. This means that we are part of different $w e^{\prime} s$, but that we see this work as a coalition across our life conditions and connected struggles. The coloniality and neoliberalism of the institutions (with and) against which we work means that some of us have lost jobs, been denied access or been met with so many brick walls (Ahmed, 2017) that make surviving in the academy difficult, if not impossible ${ }^{14}$. We have opened with this reflection on fire as a way of making sense of who we are as a collective and how we have come to the discussions we present here on what it means to decolonize anthropology.

Each of the sections in this piece are not aiming to build a linear argument or theoretical position. Instead, we present a series of dialogues, which resulted from our meeting as a group in free-flowing discussions about our individual articles and our reflections on decolonization as we came together to produce this special issue. As we discuss at the end of this piece, we decided to write something together to recognize that whilst we exist as the academic anthropologist individual, we paradoxically want to work against it. And further, the Anthropology and academia that many of us have felt and experienced in our particular locations have driven our critiques and interventions as they stand, have been felt individually but are shared between us also. Our method has been collaborative and collective in that we started with conversations on video calls. We thought of these as being much like fireside dialogues, rolling from one to another. We see each of these segments as firewood adding to a brighter flame. The fire is both the energy we have created as a group, but also the energy within each of us to challenge, question and consider our discipline with rigor and heart. Everyone who is named as an author of this article has had some input either orally, in writing, or editing, and together we have constructed and created a set of questions, arguments and provocations. We invite the reader to join us around the fire and in our collective reflections and interventions.

\section{The Kindling}

Indigenous anthropologist Zoe Todd (2016) acknowledges that we as anthropologists:

still practice our disciplines in ways that erase Indigenous bodies within our lecture halls in Europe, we unconsciously avoid engaging with contemporary Indigenous scholars and thinkers while we engage instead with eighty year old ethnographic texts or two hundred year old philosophical tomes (p. 8).

We are a discipline where Indigenous ${ }^{15}$ ideas and terminology are not considered objective when they come from the voices of Indigenous peoples from their own political, and intellectual perspectives, and instead must be legitimized by the discipline through a lens of whiteness that is commonly also ableist and cis-

heteropatriarchal. ${ }^{16}$ It is through these academic interpreters that Indigenous ideas are translated, accepted and promoted in Anthropology (Todd, 2016). The whiteness of our discipline extends to the wider infrastructures that are embedded in policies and inform our regulatory norms so that citing white cishet ${ }^{17}$ men and white cishet women is how one gets ahead in the field of Anthropology (Ahmed, 2014). And in this, anthropologists appear to be limitless, able-bodied and -minded figures who can travel unfettered and unbounded by ableist structures and geographical borders. However, despite good intentions, unless there are permanent widespread organizational changes where Indigenous communities have control of the access, interpretation, and practices that come from these projects, then colonization is still being perpetuated (Todd, 2016). Anthropology as the interpreter, purveyor, and ultimately the "owner" of culture cannot be sustained for it perpetuates colonial violence (Atalay, 2006; Pidgeon, 2016; Yellowhorn, 2012). Anthropologists who decide how and where to use ideas for their own gain without engaging directly with the political demands of Indigenous communities are in

\footnotetext{
${ }^{14}$ We want to recognize the struggle of some of the authors of the previous special issue of TA on diversity, who because of the structural racism of the academy, were close to losing their opportunity to publish and speak their truth. One of those authors was also originally part of our collective and decided to pull out of this issue because of the institutional racism they faced (Teaching Anthropology Editorial 2021). In the River and Fire Collective, we discussed how we felt about going forward with our issue, and how, if so, we could stand in solidarity with those authors at the same time. Since the journal and the editors issued an apology and the authors decided to publish, we also went ahead with our publication. However, we felt it necessary to share what went on behind the scenes, as an example of the ambivalence we feel, trying to work collectively against racism in the academic industrial complex.

15 'Indigenous' in the context of Zoe Todd's work is informed by the experience of settler-colonial violence in Turtle Island, however the nuances of Indigeneity should be contextualised for each colonial history and place.

${ }^{16}$ We use cis-heteropatriarchy to describe how patriarchal structures are closely linked to heteronormativity and cisnormativity.

${ }^{17}$ Cishet is a combination of either cis and heterosexual or cis-normativity and heteronormativity. A cis person is a person who identifies with and/or is the gender they were assigned at birth.
} 
danger of enforcing colonial violence rather than challenging it (Todd, 2016, p. 18).

\section{Is Decolonization the right concept?}

This question lingered throughout our collective conversations and writing. We discussed the importance of land within the decolonization debate (Tuck \& Yang, 2012, p. 2014), how decolonization must be linked to the political-economic inequalities between regions forged through colonialism (Bhambra et al., 2018), and whether we can, and whether we want to, decolonize institutions that are colonial and have been colonial from their inception. Olivia Barnett-Naghshineh and Antony Pattathu have laid out a trajectory of anti- and decolonial work in the introduction to this special issue (Barnett-Naghshineh \& Pattathu, 2021). This trajectory includes postcolonial scholarship/praxis, anticolonial scholarship/praxis and decolonial scholarship/praxis (amongst others). The question remains, is the work we are doing, to resist and refuse colonial permanence (Simpson, 2017) being reaffirmed, or disrupted, by (an attempt at) decolonizing anthropology? Does anthropology prevail the more we seek to reform it, or would it disappear of its own accord, without such attempts?

To understand the impossibilities and possibilities of decolonizing anthropology, we want to look into the production of knowledge, which lies at the roots of the discipline. Posing the question of whether decolonizing reaffirms the same colonial permanence that it wants to abolish, raises issues of the production of knowledge as embedded in the academy and its translation dynamics. We have stressed multiple origins for decolonial thinking, theory and praxis in this journal, and we have stressed discomfort and antagonisms with the appropriation of the term from Indigenous struggle that some of us have. We realize that the reasons we have to engage with the term or not use the term cannot be understood without looking at the localities and positionalities from which we speak (and we recognize that decolonizing is no longer the choice for many Indigenous scholars in settler-colonial contexts). For some this is the basis to reject the appropriation of the term 'decolonization' altogether, as Tuck and Yang (2012) stress, when we look at settler-colonial contexts. For others it is the basis to engage, as 'decolonial' theory and practice bears a potential to create new formations within society as we look at the European continent, to create an awareness and basis for change in regard to colonial complicities and continuities, which are yet to be built through educational institutions (Bhambra et al., 2018). If we look at Gloria Wekker's (2016, p. 2, 175) work, she engages with both postcolonial and decolonial theory, and criticizes the concept of the postcolonial, for similar reasons that we are questioning the decolonial now, namely that its increasing use leads to an inflation of the meaning and does not engage enough with questions of positionality and race. In the following section, we reflect on how a particular kind of reflexivity has become a way of legitimizing and recentering the white, cis, colonial anthropologist. White innocence (Wekker, 2016) is tied together in the discipline's engagement with reflexivity.

\section{A Second piece of firewood - Anthropological reflexivity and/as white Moves to Innocence}

In its feminist and post-modern turn Anthropology decided to take seriously the situatedness of knowledge(s), resulting in reflexivity and positionality becoming the trademark of the discipline (Haraway 1991; Abu-Lughod 1991). However, as Sara Ahmed reminds us, "[w]hen criticality becomes an ego ideal, it can participate in not seeing complicity... [so] [p]erhaps criticality as an ego ideal offers a fantasy of being seen" (2012, p. 179). It could be that over the years the discipline has fallen in love with its fantasy of being seen in the correct way, resting on its image and blinded to the haunting reality that it is perpetuating a reflexivity that failed to address the politics of knowledge production (Trouillot, 2004). Instead, what if reflexivity acts as a shield that defends Anthropology, a false mirror that protects a liberal white innocence (Jobson, 2020; Brodkin et al., 2011)? Reflexivity is critical for an honest ethnographic methodology. However, it is not enough to evade the colonial power relations when the ethnographer is white (or close to whiteness in terms of class privilege and citizenship) and working in a 'post-colonial' context.

White innocence describes the conscious or subconscious idea of a white dominant society's lack of understanding, responsibility and accountability regarding racism (Essed et al., 2019). For Wekker (2016), a nation that calls itself 'color blind' or 'progressive' (e.g., UK govt Sewell report) is in fact acting out an ongoing colonial legacy of white supremacy and specifically emanates white innocence. Anthropology has a direct relationship with the colonial structures of whiteness, as a discipline that emerged in the 19th century (e.g., Lewis Morgan) out of the colonial requirement to understand colonized and racialized people in order to make them easier to dominate and to justify this domination. Some anthropologists today may claim that those of the 20th century (e.g., Franz Boas; Levi Strauss) were the saviors and defenders of colonized peoples in their attempts to render them 'human' in the eyes of the European colonial state. However, this was by no means all 
anthropology. For much of it, whiteness, and the privileges that come with passing as white within these colonial structures, explained much of the discipline's legacies and practices (van den Berg, 2021).

As explained by Inwood (2018), the point is not to downplay the importance of white privilege, but to highlight the ways the topic of white privilege makes it easier for white people to talk about racism, by allowing them to consider involuntary socialization in isolation from historical continuities and individual accountability with regard to racism (Inwood, 2018, p. 5). Thus, while some white people would simply be racist, others consider themselves quasi-helplessly exposed to the consequences that they are privileging from. Claims for methodological reflexivity often aim toward this imaginary innocence. This tends to be a maneuver of deflection, decentering and claiming of innocence. Thus, we can consider anthropological methods of reflexivity as intertwined with white innocence - 'I have positioned myself and reflected on my power...so now I can continue on.' There seems to be a hierarchy of engaging in reflexivity in the academy, where the white cis able-bodied anthropologist is not expected to, but admired for a minimal reflexive practice, and where especially BIPOC, but also trans, gender non-conforming, queer and disabled, anthropologists and researchers are expected to reflect on their position to avoid being accused of bias and navel-gazing.

By denying racist biases, not reflecting upon privilege and how these enable research, and an imagined analytical objectivity, anthropologists (and linguists) reproduce epistemic violence concealed by white innocence (Camufingo, 2018). As Baldwin states in The Fire Next Time (1963, p.17), "It is the innocence which constitutes the crime." Just as described by Inwood, it is an innocence that perpetuates colonial continuities and leaves power relations unquestioned. Inwood (2018, p. 5) quotes Griffin (1998) "white innocence is grounded in notions of forgetfulness, erasure, denial and transcendent, all-subsuming 'freedom' or entitlement' (Griffin, 1998, p. 4)." Understanding this conceptualization of white innocence thus reveals that anti-racist accountability is about more than simply acknowledging the white privileges that are being concealed by it. This innocence has been enabled by social and historical processes (Wekker, 2016). ${ }^{18}$

When white innocence or innocence in proximity to whiteness (in terms of citizenship, cisnormativity, class etc.) is claimed, it is often a means to avoid responsibility (Inwood, 2018). Many of us have experienced

Anthropology, especially in Northern European cultural contexts, as a discipline that relies on white innocence. Through engaging with emotions and knowledge, as we do in this special issue, we find examples of the white innocence of Anthropology, that we see when the complicity of the discipline, the institution or an individual is addressed, such as when we have critiqued extractive practices, when we question who the theory is for, and when we raise questions about who can do which kind of research (Diallo \& Miskow Friborg, 2021). When we are accused of being biased, the defensiveness that comes from this kind of white Anthropology, is maintaining structural forms of discrimination to uphold the status (quo) of Anthropology.

\section{Our Third Piece of Firewood: The Split of the Anthropological Self}

To many of us, the partibility or hybridity of the anthropological self is part of our everyday existence. Hence it becomes even more explicit when we endeavor to conduct research and realize we are not able to identify with the assumed cis-hetero-able-bodied-white individual the ethnographer is assumed to be in our training. Furthermore, this Anthropological self seems not to be perceptive or conscious of their own emotionality. Instead, their head (the rational) is separated from the body and away from the heart (the emotional), resulting from the philosophical Cartesian split (Behar, 1996; Smith, 1999). Understanding this discrepancy leads us to explore how Anthropology is taught in its respective classrooms. Anthropological knowledge is conveyed as socalled 'neutral' or 'unbiased' knowledge, despite attempts to challenge this (Haraway 1988). This kind of objectivity regime has been critiqued in Black feminist, anti-colonial, Indigenous, queer and trans pedagogies and epistemologies (hooks, 1989/2014, 1994/2014; Behar, 1997; Collins, 2000; Mullings, 2005; Bolles, 2013; Nicolazzo, 2017). Such a viewpoint is conceptualized by Donna Haraway (1988, p. 581) as "the God trick of seeing everything from nowhere": the idea that you [read: white, cis, heterosexual women and men] have access to Indigenous knowledge and reproduce 'neutral' and universal knowledge from a disembodied self (Shields, 2007). Only the 'Other' is seen as emotionally embodied and thus irrational and inferior. The God trick, which Haraway discusses, similarly to Grosfoguel (2007), is also a God-I, the all-knowing individual that universally knows and captures the respective others as a generalized whole. Such modes of knowledge production are

${ }^{18}$ Yet Black, Brown and Indigenous people do not have the same chance within legal justice systems to claim innocence. Socially and historically this innocence claimed by privileged white people is often more acceptable than innocence claimed by Black, Brown and Indigenous people (Wekker 2016, p. 16-17). 
central to how 'fieldwork' within Anthropology becomes 'ethnography': there must be a clear distinction between field and home (Allen \& Jobson, 2016). It follows that the anthropologist goes 'away' on fieldwork within a specific, delimited field that they 'gain access to' through 'key informants' and 'gatekeepers'. Once 'there', the anthropologist is then supposed to work to get to know, gain trust in and 'become part of a community' through participant observation. Submerging themselves in 'the field', they let themselves go a bit but still maintain some distance and 'sense of self' (as separate from the people in the field) through the jotting down of notes and observations. When the fieldwork is 'over', the anthropologist is then supposed to 'leave the field' and 'go back home' to the university, where they then work towards regaining a 'complete analytical distance' which enables the writing 'up' of an 'objective', 'scientific', 'distanced' analysis, to form ethnography.

As Haraway (1988) describes, this is deeply embedded in the empiricist tradition - a regime of knowledge that firmly rests on the belief in objectivity and ignores the sensibilities and emotions that underpin such perception. It is blind to the prejudices behind some of our anthropological intentions to objectify and classify, and turning people who subsequently become known and knowable quantities through this anthropological process of fragmentation. This breaking down and reclassification of culture and people requires a certain detachment of the anthropologist from the people they describe. As bell hooks (2014/1989), writes:

a dimension of the oppressor/oppressed, exploiter/exploited relationship is that those who dominate are seen as subjects ${ }^{19}$ and those who are dominated, objects. As subjects, people have the right to define their own reality, establish their own identities, name their history. As objects, one's reality is defined by others, one's identity created by others, one's history named only in ways that define one's relationship to those who are subject (p. 423).

For example, consider students of Anthropology who are foremostly exposed to "classical" anthropological literature in their first years of bachelor studies. The Anthropological canon and its historicizing and essentializing of people's culture as per "the Fulanis", "the Kula ring" etc. often escapes critical reflection and despite some anthropologist's awareness of the harm this does, such texts are often still taught uncritically or without a critical sidenote. Such preconceptions are sold as truths and we grow accustomed to how the knowledgeable observer, the anthropologist, would take it upon themselves to speak on behalf of those people. Yet, presuming to know the "Other" in such a way does not allow for entitlement to speak on behalf of the people that anthropologists study; people that cannot be considered so unintelligible as unable to speak for themselves. Yet self-determination is denied by those authoritative figures, like field experts, who are called on to explain local events like uprisings, court cases, land-contestations or elections, to a Western audience. Is the need for translation viable or does it pertain to a move to innocence as well? Who is actually entitled to speak, where, when, how and about what becomes critical to which stories are heard, and which voices are recognized (Spivak, 1988; Camufingo, 2018; 2021).

\section{The Fourth Piece of Firewood: Ethics of Accountability vs Reflexivity}

An ethics of accountability is relational and evolves from the location where knowledge is shared and produced between people (anthropologists, researchers, activists) and the environment. Thus, an ethics of accountability is situated in the relational field of producing knowledge. Ethics within anthropology are often seen as optional and are understood as a guideline, or down to individual discretion. This seems to be the case the bigger the structural and relational distance. University institutional ethics have become more routine in anthropological research, to protect the institutions we work for and interlocutors. Yet while the moral practice that has come to be connected to ethics is something that is reflexively, but fleetingly, addressed in our classrooms, it is not something that we necessarily have to engage in or are held accountable for directly. Taking an ethics of accountability seriously for (activist) anthropological research, and thinking, means to center the struggles and communities we work with and/or are from and consider the implications of our knowledge for them as well as the ongoing relationships we have to them. Furthermore, it is important to have sufficient flexibility to allow for in situ ethics to be collaborative and context specific. Many of us who turn the lens of study onto whiteness, the discipline, the university, or other hubs of power within "the center" have time and again experienced how "ethics" turns into an institutional leverage to gatekeep the (liberal) institution, the discipline and whiteness itself. Exposed to more stringent ethical guidelines than our colleagues who conduct more "traditional" anthropology, we are often faced with a protective ethical bureaucracy utilizing heavily loaded terms such as "risky" or "sensitive", effectively inhibiting our ability to intersubjectively create knowledge on issues that could be

${ }^{19}$ We recognize that the use of subject/object can have different meanings depending on the theoretical perspective. 
threatening to the workings of whiteness (Klinkert 2021; Fabian, 2012).

This centering needs to be part of how we think of and create a so-called 'end product', traditionally taking the form of a monograph or a series of peer-reviewed academic articles (our academic capital). This valuable knowledge can be co-created and shared in workshops, podcasts, zines, and archives and thus made accessible in multiple ways including during the process of creating the knowledge. For example, this could involve cobuilding theoretical frameworks that has relevance to the lives of the people we work with, as well as being transparent throughout the process about what conclusions we are coming to through the research. If the project is collaborative from the outset, analysis happens throughout the research process, in relationship with the people we work with, and then the theorizing and the doing of research become less distinct between the ethnographer and the 'field'. The communities we work with and from can be part of the process of building ethnographic theory, and thus the knowledge creation processes become interrelated with our ethical conduct (Tengan, 2005). These ethics are rooted in a desire to produce accountable knowledge which is for the people rather than the neoliberal academy (Hammana \& Klinkert, 2021). This is in opposition to what we, alongside others, see as an extraction model of anthropology (Hammana \& Klinkert, 2021; TallBear, 2014, Harrison 2010).

As researchers and as anthropologists, we need to ask ourselves "for whom do we really write?" Often, our contributions look more like individual explorations of a social issue in a particular place, which we are newcomers to, and of which we are interpreters. Our interpretation, and theorization, is often derived from a corpus of anthropological knowledge on this particular issue or region, and we write and publish our texts in English, or another colonial language, sometimes inaccessible to the people we write about. It might be a bold question, but what really is the value of a cultural account of a place the anthropologist has no ongoing relation to and often cannot return due to institutional barriers? Kim TallBear (2014) writes about staying in good relations with her colleagues, of whom include what many other anthropological projects consider as 'informants'. 'Staying in good relation' means that she does not disappear after someone has helped her in her project. Rather, she inhabits the communities whom she works with, and is interested in "studying across" instead of studying up or down. TallBear writes that "A researcher who is willing to learn how to "stand with" a community of subjects is willing to be altered, to revise her stakes in the knowledge to be produced" (TallBear, 2014 , p. 2). What happens if we allow our interlocutors to alter, revise or disagree with our own interpretations (see for example Barnett-Naghshineh, 2021), or better yet, what if we do not make those distinctions in the first place (Hammana \& Klinkert, 2021)?

Many of us think with and through an ethics of accountability as well as the importance of reflexivity and positionality in research. In anthropological texts, reflexivity and positionality can be limited to a confessional style check list of, 'yes, I am a white (cis) man/woman, and I know that this affects my data'. We see several problems with this. Looking at the number of Black people in permanent tenure in Northern European universities, and diversity in general, it is evident that the academy is mostly only satisfied with such an approach to positioning when the author and anthropologist in question is writing from a privileged position of being white and cis. As racialized, Indigenous, as well as queer and trans people, we are more often challenged on our objectivity, particularly when studying in and from our own experiences and the communities we are part of (Diallo \& Miskow Friborg, 2021; see also Abrahams, 2021). Second, positioning is relational and should be accountable, meaning that writings on positionality in research should include descriptions of your relationships to people whom you create knowledge with as well as how you create knowledge together (see e.g., Wekker, 2006; Nicolazzo, 2017). Lastly, an ethics of accountability, rather than reflexivity, means to critically examine the understanding of the anthropologist as an interpreter and theorizer of the "experience" of the so-called "informants" (on similar discussions see Kilomba, 2010; hooks, 1989/2014, Smith, 1999). When working with an ethics of accountability we aim to dissolve hierarchies of knowledge which render knowledge created within the neoliberal university as different from and more valuable than 'experience' and move towards co-theorizing and thinking with rather than about the people we work with in our research (Jourian \& Nicolazzo, 2017; TallBear, 2014). An ethics of accountability looks for ways to question the authority of the author as sole interpreter and actively holding ourselves accountable for how we write about people. Who even gets to write and about what? If the field is away, and never home, and the anthropologist leaves 'the field' and stays distant, it seems to be very easy to escape accountability. When 'theory' is understood to be produced in and for the academy, and maybe mediated to the so-called 'informants' (still the dominant term rather than interlocutors in many European anthropology classrooms) in an accessible language presented as 'a gift given back to the field' (TallBear 2014), who is there to hold you accountable? Rather, we should work towards thinking about how we can create a community of researchers who hold each other accountable with love and understanding, but also ensure we truly reflect in the presence of others, and not within the assumed capacity for individual reflexivity. 
Being accountable to our research collaborators and colleagues and ensuring there is space for reflection from outside of ourselves, is another counter to the white innocence of Anthropology.

\section{Firewood Five: The Problem of Language}

As has been brought up in previous sections, language permeates so many dimensions of what we do in anthropology, not least because it is often the basis for our interactions with our interlocutors and undeniably determines who is hired and published within the Academic Industrial Complex (Diallo \& Miskow Friborg, 2021; Hammana \& Klinkert, 2021). For many of us this means using English or some other colonial language. Writing this piece has meant putting aside many of our own languages, colonial and Indigenous. Writing in a form of US Academic English enables us to work together, but also may erase our specific realities as we try to translate our experiences while at the same time holding space for differences. This ambivalence toward language(s) in our collaboration mirrors the dichotomy of belonging and not-belonging within the colonized structure of the discipline that we have been thinking and writing about. Writing and thinking in colonial language(s) means being entwined in the histories and presents of white supremacist, colonial, capitalist, ableist, cis-hetero patriarchal systems of power that condition our (im)possibilities for existence and self-determination. Our histories cross space and time often in contexts of forced removal, diaspora and new imaginings of community. We repeatedly face questions about authenticity and positioning of self through language, sometimes in situations of language loss or as heritage language speakers. The Black queer nonbinary poet and activist Cicely Belle Blain (2020), explores this paradox in their poem, "Dear Diaspora Child":

it's okay if you've never even set foot on the soil of your people.(...)

it's okay if you understand but can't reply. (p.70)

We recognize the emotive hold of language on identity and on possibilities for being, living and relating to each other. We interrogate the extent to which language acts as a unifying force and where it starts to erode ideas of self and community. We are haunted by language in our connections to lands, to relationships with elders, to family and cultural histories; yet, turning to the fire metaphor, we also envision ways in which language, through the harnessing of its emotive energy, can subvert or reappropriate power: how might the reinvention and reconfiguration of (also scholarly) identity and relational possibilities through language be part of the decolonization processes in anthropology and what might be the implication for our places of learning for reimagining language in this way? What if anthropology became the space where we can find ourselves, reconnect with our origins, and learn our languages for the sake of this connection and not for the sake of expropriation or appropriation? What if this was a means of "returning to common use" (Hammana \& Klinkert, 2021) and a means of commoning (Pattathu 2021; Chaudhuri-Brill, 2021)?

The impact of colonization on Indigenous languages ranges from intentional linguicide, to language change through contact and mixing with the colonial language(s), to language loss by native speakers and the creation of heritage language speakers, who no longer learn the language as a mother tongue or who learn it outside of the Indigenous context. Indigenous communities on Turtle Island, in Canada's colonies for example, were persecuted for speaking their Indigenous languages within and outside of the academy. Indigenous people were aggressively assimilated via the Gradual Assimilation Act, while the Bagot Commission, the Report on Native Education with Egerton Ryerson, and the Indian Act designed the residential school system, with a focus on separating families, agricultural training in the form of servitude, and Christian instruction in English (Miller, 1991; Government of Canada, 1898; Judge et al., 2021). Similar forced language assimilation processes have taken place on European soil against the Roma, resulting in several generations that have lost Romani as a first language (Crowe, 1994; Hancock, 1987). This is also the case for the language Kalaallisut (Greenlandic), (for illustration see the work of Niviâna, 2019) or in the context of Sámi languages of Finland, Norway, Sweden and the Kola Peninsula (Fjellgren \& Huss, 2019; Jernsletten \& Storfjell, 2017; Scheller, 2013).

In the wake of such language extinction policies, what are the implications for language revitalization and acquisition by younger generations and how could a reformed or transformed anthropology be part of this? Could the dominance of the colonial language be countered by acknowledging where Indigenous language forms have been co-opted by the broader culture? The iconic Canadian "eh", for example, appears in the Canadian Encyclopedia as an original Canadian quirk (Wright, 2016), without recognizing that in reality it is simply how Nishnaabeg say 'yes' ('enh'). Similarly, the Roma and Amazigh have long argued for their own ethnonyms to be used to refer to them rather than pejorative outsider terms such as Gypsy or Tsigane or Berber. Giving back linguistic autonomy in such ways is a form of recognizing and legitimizing identity. 
The way in which particular persons come to inhabit particular spaces is also an important consideration in thinking about how language might be re-imagined in the classroom. Often time, in and around European classroom environments Black, Indigenous and People of Color (BIPOC) are subject to whiteness and constantly have to adjust their speech, the tone thereof, and their bodily comportment, in order to comply (see Diallo \& Miskow-Friborg, 2021; Doharty, 2020; see also Faison, 2018; Ahmed, 2007; 2012). Particularly, women, femmes and transfeminine nonbinary and gender non-confirming people who are BIPOC have to be strategic about the emotions they make manifest in their respective environments. This is what Doharty refers to as "racialized emotions" (Doharty, 2020, p. 555). Black women are, for example, "perceived as more hostile when they display the same ambiguously aggressive behavior as white people" (Duncan, 1996, as cited in Rabelo et al., 2020, p. 3). But in attempting to curtail the expression of their emotions in order to avoid being stereotyped, they run the risk of confirming those very stereotypes (see Doharty, 2020). Ultimately, however, Black women and women of Color, have to be strategic about the emotions they show in order to endure in these spaces (Doharty, 2020).

What, then, is the tone in which we can speak? And what are we permitted to say? (Kilomba, 2010). Are our spaces of learning contexts in which all our possibilities can be realized? Which lives and possibilities for existing, being and relating come into being, and which are in turn erased and limited, through language?

In this collaborative piece we have negotiated the problem of language with each other, based on the experiences in the institutions, communities, coalitions and organizing spaces that we have been, or are, a part of. Based on the academic language that we learned (often English) and how we take conscious steps to transpose it. We negotiated the way we want to create a caring space for each other in the process of how this piece was created. We discussed the power relations present in our coming together and how we will be heard, who might be harmed by our words, as well as those who will refuse to listen because of the fear of losing dominance. We also had to listen, learn and unlearn as part of this process of coming together. Overcoming these gaps of communication by taking responsibility means becoming radically human with each other, accepting different stand points and still finding a voice together, which is not univocal, but rather manifold. This is one of the steps to overcome the silencing of the oppressive structures of society and the academy. This is another firewood we put onto our fire.

\section{Keeping the Fire Burning - Collaborative Writing}

\section{Writing Together and Writing Apart}

We have used different modalities of collectivity throughout the journey of working together on this special issue. Whether it be this collective piece of writing that we are all involved in, or the pairs and smaller groups for our other pieces of writing. These different modalities of collectivity have all had different methodologies, some of which we would like to expand on in this final section.

To write this piece as a collective, we have used a number of means to come together, most of which have been by online technologies in the context of the COVID-19 pandemic. We began by having weekly and then bimonthly meetings where we discussed questions that came up around the notion of 'decolonizing' in an organic dialogue. This often began with someone posing a question or problem to the people who were present at the meeting. As we began to realize what we were doing was collectively thinking about decolonization, we created a shared online document to get down our notes. We devised a system where one person would take notes whilst another was speaking. We then eventually turned this document of segments of dialogues into themes, which were broken into sections allocated to smaller work groups. In some cases, we have developed the sections we ourselves spoke in during the initial moment of dialogue. In other moments, we have picked up topics which we were engaged in through the dialogue and continued to expand them together. We then continued to meet online and in breakout rooms and discussed particular sections and wrote them as we were logged into the document together. At times we discussed matters as a whole group, sometimes with nine or ten people present in a meeting, sometimes through dialogue boxes in the document. At other times, we wrote into the document during the same time period but not actually communicating with one another. The dialogue was always documented, developed and written into text by more than one person. In this sense, those of us whose names are on this collaborative article have all had some input either in oral, writing or editing forms. 


\section{Working Against Competitive Individuality in the Neoliberal University}

As we have attempted to unpack in the previous sections, working within the academy, and working within the discipline of a western Anthropology, is a continuous process of being subjugated into a neoliberal professional and individuated system. It is through these various processes we have to navigate our academic work. We are pitted against each other to compete for positions, for funding, for publications. We compete to be able to survive in the academy. One of the ways we want to counter the neoliberal system of academia and the discipline of Anthropology, where the number of citations is how universities are ranked and research is valued (over teaching), is by actually writing together. We consider writing collaboratively as a form of healing from these individuating structures and economies of authorship that we are forced to work in, i.e., individually authored articles have more prestige than collaborative articles in humanities, especially when our starting point is marginalization (Harney \& Moten, 2013; Bacchetta et al., 2018). This healing happens in different ways. It happens through learning from and with each other, sharing our gifts with each other, challenging and keeping each other accountable, and it happens through the attempts of refusing to write for academia's sake only but also working to engage different publics in our work (as we each do individually and hope to do more as a collective). This healing happens collectively, in and beyond the academy, in our communities. Healing is something that moves through a form of sociality. If we say that healing is intricately tied with care, then we can say that care is an expression of and a way to uphold collectivity. It is, for sure, a way to uphold conviviality, precisely because conviviality, in its etymological roots, means living together and we cannot live together without care. Through writing together, we can care for one another and for the world we want to build on the ashes of what is already burning. This work of refusing the individuated competitive neoliberal model through writing together is a form of care. Maybe more aptly phrased, we formulate a methodology of care through writing together.

Interestingly, cura, which is the Latin for cure and also found in the etymology of care, is present also in the word 'curate'. In a way when we are curating a collaborative piece like this, we are involved in doing cura, involved in care work with and for each other, to heal from the violent structures in which we are forced to work/write. This means that when writing together we also give ourselves the opportunity to enhance the voice and critique of those of us who have been silenced, and to give those of us with more power and privilege the opportunity to listen. We think, speak and write in collectivity, honoring the knowledge traditions of queer and trans people who are Black, Indigenous and People of Color who have been and continue to go against the individualistic, extractivist, colonial mainstream (Haritaworn et al., 2018).

When writing together, we also meditate on how we become one. And more importantly, if we should even strive towards becoming so. When writing together we can hold space for each other, insisting on not speaking with one unified voice and delivering one universal truth or statement. Speaking as a collective working towards a common goal, which is anti-colonial and abolitionist, but with many voices, means to open up and hold space for multiplicity and the possibilities of multiple coexisting interpretations both within our collective and our writing. A collective therefore requires not aspiring to a homogeneous voice but instead allowing for a plurality of voices to be heard and considered - and this is what we have attempted with this piece and the Special Issue. In this way it may correspond more with some Indigenous research methodologies by upholding the values of relational responsibility and contradicts the power dynamics upheld in westernized and individualized academic settings (Smith, 1999; Smith et al., 2019). When we present bold critiques, we have much more strength as a collective, and we are able to support each other in countering the oppressive structures that we are all affected by, albeit in different ways. As Fred Moten and Stefano Harney so astutely put it:

\footnotetext{
Writing alone, by and as oneself, leads to brokenness. Writing together can generate incompleteness. We live with brokenness, but we can also live with incompleteness, a shared brokenness, an open wholeness, that generates potentialities that go past the point of the unseemly for those who impose normativity and even for those who desire norms that will have moved against the grain of such imposition. To take up a special case, we often hear that the university discourages writing together, and rewards writing alone. We have ourselves said this, and it is true. But truer is the fact that we don't want to write together. We are the first guardians of our posited individual contribution. (...) So, we should write together to incomplete each other. It may not cure our brokenness, but that is only because we are incurable, or to put it another way, our cura, our care, can never be of the self, but only of that touch, that rub, that press, that kinky tangle of our incomplete sharing." (Goméz Alvarado et al., 2018, para.15)
}

Sharing brokenness and holding space for incompleteness are a source of knowledge and wisdom that we can care for and grow collectively (Piepzna-Samarasinha, 2019; Raha, 2017). 


\section{The River and Fire Collective}

As you have read this piece, we hope that we were able to communicate some of our river's energy and our fire and ignite your own critical reflections. In Anishinaabe culture, fire always starts the ceremony. Similarly, to open up the New Year, Iranian tradition is to jump over fire, to cleanse the self of the previous year and open afresh to the new. Here we started with fire and its radical and revolutionary potential and explained the significance of abolition not just for destruction but also for clearing the way for something new. Now we end with water, acknowledging all of our different contributions and the fact we may take on different positions at different times and together we form a river.

We want to reconnect the head and the heart in academia, the mind and the body and not tear the self from the collective and other living beings. We have come together to show the power of emotions for moving people to action, learning and unlearning, reflecting, and becoming anew. Here we come together to celebrate the transformative, life-affirming powers of Rivers and Fire.

Through this work, we have become The River and Fire Collective.

\section{References}

Abrahams, N. (2021). On being a space invader and the thing around my neck: Navigating white educational space as a (Muslim) researcher of colour. Teaching Anthropology Journal, 10(4), 73-83.

Abu-Lughod, L. (1991). Writing against culture. In Fox, R. (Ed.), Recapturing anthropology: Working in the present. (pp. 137-162), School of American Research Press.

Ahmed, S. (2007). A phenomenology of whiteness. Feminist Theory, 8(2), 149-168.

---- (2012). On Being Included: Racism and Diversity in Institutional Life. Duke University Press. https://doi.org/10.1215/9780822395324

---- (2014). The Cultural Politics of Emotion. Edinburgh University Press. https://doi.org/10.4324/9780203700372(Original work published 2004)

---- (2017). Living a Feminist Life. Duke University Press. https://doi.org/10.1215/9780822373377

Allen, J. \& Jobson, R. C. (2016). The Decolonizing Generation: (Race and) Theory in anthropology since the Eighties. Current anthropology, 57(2), 129-148. DOI:10.1086/685502

Atalay, S. (2006). Indigenous archaeology as decolonizing practice. American Indian Quarterly, 30(3/4), 280-310.

Bacchetta, P., El-Tayeb, F., Haritaworn J., Hernandez, J., Smythe, S., Thompson, V. E. \& Willoughby-Herard, T. (2018). Queer of Color Space-Making in and beyond the Academic Industrial Complex. Critical Ethnic Studies, 4(1), 44-63. https://doi.org/10.5749/ jcritethnstud.4.1.0044

Baldwin, J. (1963). The Fire Next Time. Dial Press.

Barnett-Naghshineh, O. (2021 (forthcoming)) “What Women Want: Fashion, Morality and Gendered Subjectivities in the Highlands of Papua New Guinea" Critical Studies in Beanty and Fashion.

Barnett-Naghshineh, O. \& Pattathu, A. (2021). Introduction to the Special Issue: Decolonizing Anthropology: Race, Emotions and Pedagogies in the European Classroom. Teaching Anthropology Journal, 10(4), 1-16.

Behar, R. (1996). The Vulnerable Observer: Anthropology that Breaks Your Heart. Beacon Press.

Bhambra, G. K., Gebrial, D. \& Nişancioğlu, K. (2018). Introduction. Decolonizing the University? In Bhambra, G. K., Gebrial, D. \& Nişancioğlu, K (Eds.), Decoloniz̨ing the University. Pluto Press.

Blain, C. B. (2020). Burning Sugar. Poems. VS Books. Arsenal Pulp Press. 
Bolles, L. (2013). Telling the story straight: Black feminist intellectual thought in anthropology. Transforming Anthropology, 21(1), 57-71. https://doi.org/10.1111/traa.12000

Brodkin, K., Morgen, S. \& Hutchinson, J. (2011). Anthropology as a White Public Space. American Anthropologist, 113(4), 545-556. https://doi.org/10.1111/j.1548-1433.2011.01368.x

Brown, A. M. (2017). Emergent strategy: Shaping change, changing worlds. AK Press.

Camufingo, F. A. (2018). white Feelings and Black Knowledge: Tackling Racism and Epistemic Violence in German Higher Education. Cite Journal, 1(1), 7-15. doi: 10.33137/incite.1.28916

Camufingo, A. (2021). When We feel: Racialized Emotions and Epistemic Violence in German Higher Education. Teaching Anthropology Journal, 10(4), 58-67.

Chaudhuri-Brill, S. (2021). Reflections on East and West: Anthropology, Decolonization, and Teaching. Teaching Anthropology Journal, 10(4), 84-91.

Clare, E. (2017). Brilliant imperfection: Grappling with cure. Duke University Press.

Collins, P. H. (2000) Black Feminist Thought. Routledge.

Crowe, D. (1994). A History of the Gypsies of Eastern Europe and Russia, St. Martin's Press.

Diallo, O.-K. M. \& Miskow Friborg, N. (2021). Subverting the white cis gaze: Towards a pedagogy of discomfort, accountability and care in the anthropology classroom. Teaching Anthropology Journal. $10(4), 17-35$.

DiGiacamo, S. M. (1997). The new internal colonialism. Critique of Anthropology, 17(1), 91-97.

Doharty, N. (2020). The 'angry black woman' as intellectual bondage: Being strategically emotional on the academic plantation. Race Ethnicity and Education, 23(4), 548-562. https://doi.org/10.1080/13613324.2019.1679751

El-Tayeb, F. (2011). European others: Queering etbnicity in postnational Europe. University of Minnesota Press.

Essed, P., Farquharson, K., Pillay, K., \& White, E. J. (2019). Relating Worlds of Racism: Dehumanisation, Belonging, and the Normativity of European Whiteness. Palgrave Macmillan. 10.1007/978-3-319-78990-3

Fabian, J. (2012). Cultural anthropology and the question of knowledge*. Journal of the Royal Anthropological Institute, 18(2), 439-453. DOI: 10.2307/41507968

Faison, W. (2018). Black bodies, black language: Exploring the use of black language as a tool of survival in the writing center. The Peer Review, (Constellating Stories 2.1 (Special Issue))

Fjellgren, P., \& Huss, L. (2019). Overcoming Silence and Sorrow: Sami Language Revitalization in Sweden. International Journal of Human Rights Education, 3(1), 4.

Geertz (1988). Thick description: toward an interpretive theory of culture. High Points in Anthropology, 531-552.

Gilmore, R. W. (2007). Golden gulag: Prisons, surplus, crisis, and opposition in globalizing California (Vol. 21). University of California Press.

Gómez Alvarado, Y., Anaya, J. P., Concheiro, L., Rivera Garza, C. \& Hernández, A. (2018, September 5). Conversación Los Abajocomunes. Stefano Harney and Fred Moten in Conversation on the Occasion of the Spanish Translation of The Undercommons. The New Inquiry, https://thenewinquiry.com/conversacion-los-abajocomunes/ 
Government of Canada. (1898). Statistics respecting Indian schools with Dr. Ryerson's report of 1847 attached. Ottawa: Government Printing Bureau.

Green, K. M. \& Bey, M. (2017). Where Black Feminist Thought and Trans* Feminism Meet: A Conversation. Souls, 19(4), 438-454. DOI: $10.1080 / 10999949.2018 .1434365$

Griffin, G. B. (1998). Speaking of whiteness: Disrupting white innocence. The Journal of the Midwest Modern Language Association, 31(3), 3-14.

Grosfoguel, R. (2007). The epistemic decolonial turn: Beyond political-economy paradigms. Cultural studies, 21(23), 211-223. https://doi.org/10.1080/09502380601162514

Hammana, Z., \& Klinkert, V. L. (2021 (forthcoming)). Glitching the University Machine. Teaching Anthropology Journal, 10(4), 36-46.

Hancock, I. (1987). The Pariah Syndrome. Ann Arbor: Karoma Publishers, Inc.

Haraway, D. (1988). Situated Knowledges: The Science Question in Feminism and the Privilege of Partial Perspective. Feminist Studies, 14(3), 575-599. https://doi.org/10.2307/3178066

--- (1991). Simians, Cyborgs and Women. The Reinvention of Nature. Routledge.

Haritaworn, J., Moussa, G., \& Ware, S. M. (Eds.). (2018). Marvellous Grounds: Queer of Colour Histories of Toronto, Between the Lines.

Harney, S., \& Moten, F. (2013). The Undercommons: Fugitive Planning \& Black study. Minor Compositions. https://www.minorcompositions.info/wp-content/uploads/2013/04/undercommons-web.pdf

Harrison, F. V (2008). Outsider within: reworking anthropology in the global age. University of Illinois Press.

Harrison, F. (Ed). 2010 [1991]. Decolonizing anthropology: moving further toward an anthropology for liberation. Association of Black Anthropologists, American Anthropological Association.

hooks, b. ([1989]2014). Talking Back: Thinking Feminist, Thinking Black. Routledge. https://doi.org/10.4324/9781315743134(Original work published 1989)

--- (2014). Teaching to Transgress. Education as the Practice of Freedom. Routledge. https://doi.org/10.4324/9780203700280 (Original work published 1994)

Inwood, J. F. J. (2018). "It is the innocence which constitutes the crime": Political geographies of white supremacy, the construction of white innocence, and the Flint water crisis. Geography Compass, 12(3), e12361. https://doi.org/10.1111/gec3.12361

Jernsletten, K., \& Storfjell, T. (2017). Re-reading Knut Hamsun in collaboration with place in Lule Sámi Nordlándda. In Körber, L-A., MacKenzie, S., Westerstahl Stenport, A. (Eds.), Arctic Environmental Modernities: From the Age of Polar Exploration to the Era of the Anthropocene, (pp. 87-105), Palgrave Macmillan.

Jobson, R. C. (2020). The Case for Letting Anthropology Burn: Sociocultural Anthropology in 2019. American Anthropologist, 122(2), 259-271. doi: 10.1111/aman.13398.

Jourian, T.J. \& Nicolazzo, Z. (2017). Bringing our communities to the research table: the liberatory potential of collaborative methodological practices alongside LGBTQ participants. Educational Action Research, 25(4), 594-609. DOI: 10.1080/09650792.2016.1203343.

Judge, A., Fukuzawa, S., \& Ferrier, J. (2021 (forthcoming)). Local Indigenous ways of knowing and learning in the classroom through Community-engaged learning. Teaching Anthropology Journal, 10(4), 47-57. 
Klinkert, V.L. (2021 (forthcoming)). Humbling anthropology: Ego reflexivus and white ignorance. HAU: Journal of Ethnographic Theory.

Kilomba, G. (2010). Plantation Memories: Episodes of Everyday Racism. UNRAST-Verlag.

Lorde, A. (1984). Sister Outsider. Random House.

Lugones, M. (2010). Toward a Decolonial Feminism. Hypatia 25(4), 742-759. https://doi.org/10.1111/j.15272001.2010.01137.x

Maldonado-Torres, (2007) On the coloniality of being: Contributions to the development of a concept. Cultural Studies, 21(2-3), 240-270. https://doi.org/10.1080/09502380601162548

Miller, J. R. (1991). Skyscrapers Hide the Heavens: A History of Indian-white Relations, University of Toronto Press.

Mullings, L. (2005). Interrogating Racism: Toward an Antiracist Anthropology. Annual Review of Anthropology, 34, 667-93. https://doi.org/10.1146/annurev.anthro.32.061002.093435

Nicolazzo, Z. (2017). Imagining a Trans* Epistemology: What Liberation Thinks Like in Postsecondary Education. Urban Education, 56(3), 511-536. DOI: 10.1177/0042085917697203

Niviâna, A. (2019). Switch. In Ninos Josef (eds.) Actualise Utopia. From dreams to reality. "An anthology about racial barriers in the structure of the Nordic Arts Field.", (pp. 147-154), Kulturradet.

Nyamnjoh, F. B. (2016). \# RhodesMustFall: Nibbling at resilient colonialism in South Africa. Langaa rpcig.

Olufemi, L. (2021). Experiments in imagining otherwise. Hajar Press.

Pattathu, A. (2021 forthcoming). Decolonizing Anthropology and/as Education? In Weitdmann, N. \& Porr, M. (Eds.), One World Anthropology and Beyond. A Multidisciplinary Engagement with the Work. of Tim Ingold. Routledge.

Pidgeon, M. (2016). More than a checklist: Meaningful Indigenous inclusion in higher education. Social inclusion, 4(1), 77-91. 10.17645/si.v4i1.436

Piepzna-Samarasinha, L. L. (2019). Care work: Dreaming disability justice (Fourth Printing). Arsenal Pulp Press. (Original work published 2018)

Rabelo, V. C., Robotham, K. J., \& McCluney, C. L. (2020). “Against a sharp white background”: How black women experience the white gaze at work. Gender, Work \& Organization, 28(5).

Raha, N. (2017), 'Transfeminine Brokenness, Radical Transfeminism', South Atlantic Quarterly, 116(3): 632-646. https://doi.org/10.1215/00382876-3961754

Scheller, E. (2013). Kola Sami language revitalisation-opportunities and challenges. In Andersson, K. (ed.), L'Image du Sápmi II: études comparées / textes réunis par Kajsa Andersson. Humanistica Oerebroensia. Artes et linguae 16. Örebro University, 392-421.

Shange, S. (2019). Progressive dystopia: abolition, anthropology, and race in the new San Francisco. Duke University Press. https://doi.org/10.1080/01419870.2020.1867220

Sharpe, C. (2016, November 16). Lose your kin. The New Inquiry. https://thenewinquiry.com/lose-your-kin/

Shields, S. (2007). Passionate Men, Emotional Women: Psychology Constructs Gender Difference in the Late 19th Century, History of Psychology, 10(2), 92-110. 
Simpson, L. B. (2017). As we have always done: Indigenous freedom through radical resistance. University of Minnesota Press. https://doi.org/10.5749/j.ctt1pwt77c

Smith C. A., Williams, E. L., Wadud, IA., Pirtle, W. N. L., The Cite Black Women Collective (2021). Cite Black Women: A Critical Praxis (A Statement). Feminist Anthropology 2(1), 10-17. https://doi.org/10.1002/fea2.12040

Smith, L. T. (1999). Decolonizing methodologies: Research and Indigenous Peoples. Zed Books.

Smith, L. T., Tuck, E., \& Yang, K. W. (2019). Indigenous and decolonizing studies in education: Mapping the long view. Routledge. https://doi.org/10.4324/9780429505010

Spade, D. (2011). Some very basic tips for making higher education more accessible to trans students and rethinking how we talk about gendered bodies. Radical Teacher, 92(1), 57-62.

--- (2014). R-Words: Refusing Research. In Paris, D. \& Winn, M. T. (Eds.), Humanizing Research: Decolonizing Qualitative Inquiry with Youth and Communities. SAGE Publications. https://dx.doi.org/10.4135/9781544329611.n12

--- (2015). Normal Life. Administrative Violence, Critical Trans Politics, and the Limits of Law (Revised and expanded ed.). Duke University Press. https://doi.org/10.1215/9780822374794 (Original work published 2011)

Spivak, G. C. (1988). Can the Subaltern Speak? Die Philosophin, 14(27), 42-58. 10.5840/philosophin200314275

Stark, H. K. (2012). Marked by fire: Anishinaabe articulations of nationhood in treaty making with the United States and Canada. American Indian Quarterly, 36(2), 119-149.

TallBear, K. (2014). Standing with and speaking as faith: A feminist-indigenous approach to inquiry Research note]. Journal of Research Practice, 10(2), Article N17. http://jrp.icaap.org/index.php/irp/article/view/405/371

Teaching Anthropology Editorial Board, Special Issue Editorial Collective (2021). Afterword: Critical Reflections on the Processes of Publishing about Diversity. Teaching Anthropology Journal, 10 (1), 101 102.

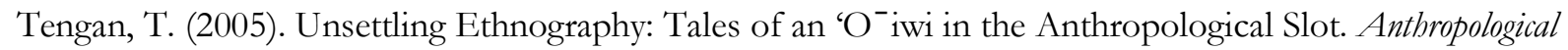
Forum, 15(3), 247-256. https://doi.org/10.1080/00664670500282030

Todd, Z. (2016). An Indigenous Feminist's take on the Ontological Turn: 'Ontology' is just another word for Colonialism. Journal of Historical Sociology, 29(1), 4-22. https://doi.org/10.1111/johs.12124

Trouillot, M-R. (2004). The North Atlantic Universals. In Wallerstein, I. (ed.), The Modern World-System in the Longue Durée. Rutledge, 229-37.

--- (2015). Silencing the Past: Power and the Production of History. Beacon Press (Original work published 1995)

Tuck, E., \& Yang, K. W. (2012). Decolonization is not a metaphor. Decolonization: Indigeneity, Education \& Society, $1(1), 1-40$.

--- (2014). R-Words: Refusing Research. In Paris, D. \& Winn, M. T. (Eds.), Humanizing Researcb: Decolonizing Qualitative Inquiry with Youth and Communities. SAGE Publications.

https://dx.doi.org/10.4135/9781544329611.n12

van den Berg, L. (2021). On learning and unlearning 'objective‘ anthropology. Teaching Anthropology Journal, 10(4), 68-72. 
Wekker, G. (2006). The politics of passion: Women's sexual culture in the Afro-Surinamese diaspora. Columbia University Press.

---- (2016). White Innocence: Paradoxes of Colonialism and Race. Duke University Press. https://doi.org/10.1215/9780822374565

Wright, K. (2016). "Eh” | The Canadian Encyclopedia. https://www.thecanadianencyclopedia.ca/en/article/eh

Yellowhorn, E. (2012). Brave New Digs: Archaeology and Aboriginal People in British Columbia, Canada. The Canadian Journal of Native Studies, 32(1), 87-99.

Disclosure statement: No potential conflict of interest was reported by the authors. 